\title{
DAMPAK PEMANFAATAN LAHAN PERKARANGAN RUMAH OLEH WANITA TANI BINAAN BALAI PENYULUHAN PERTANIAN (Studi Kasus Didesa Pekalobean, Kecamatan Anggeraja, Kabupaten Enrekang)
}

\author{
Oleh \\ Rosdah $^{1}$, Yusriadi ${ }^{2}$, Nurhaedah ${ }^{3}$ \\ Email : Rosdanaghkiky@yahoo.co.id ${ }^{1}$, yusry_ady@yahoo.co.id ${ }^{2}$ \\ ${ }^{1}$ Prodi Pertanian Agribisnis Fakultas Pertanian, Peternakan dan Perikanan \\ Universitas Muhammadiyah Parepare \\ ${ }^{2,3}$ Prodi Pertanian Agribisnis Fakultas Pertanian, Peternakan dan Perikanan \\ Universitas Muhammadiyah Parepare
}

\begin{abstract}
Utilization of Home Yard by Women Farmers is one of the flagship programs of the Office of the Agricultural Counseling Agency, Aggeraja District, Enrekang Regency with the aim of providing direction or guidance for women farmers to use their home yards intensively so that the development and utilization of yard areas can be maximally developed or enhanced. This study aims to determine the skill level of female farmers in intensive use of homestead land and to determine the level of success of the female farmer empowerment program in utilizing homestead land in Pekalobean Village, Anggeraja District, Enrekang Regency. The population in this study were all female farmers who were members of the female farmer group (198 people). This research was conducted from August to September 2020, located in Pekalobean village, Anggeraja District, Enrekang Regency. The sample was determined using the simple random sampling method where the number of samples taken was $10 \%$ of the population. The data collection method used was observation, interviews, questionnaires. The data analysis used is descriptive quantitative analysis using the Likert scale method. The results of this study indicate that the impact of land use by women farmers is very high with a total score of 1,149 with a success rate of $99.99 \%$. This has a positive impact on female farming women and can be developed sustainably in Pekalobean Village, Anggeraja District, Enrekang Regency.
\end{abstract}

\section{Keywords: Yard land, farmer woman, Likert scale}

\begin{abstract}
ABSTRAK
Pemanfaatan Lahan Pekarangan Rumah Oleh Wanita Tani adalah salah satu program unggulan Kantor Balai Penyuluhan Pertanian KecamatanAnggeraja, Kabupaten Enrekang dengan tujuan memberikan arahan atau binaan bagi wanita tani untuk memanfaatkan lahan pekarangan rumahnya secara intensif sehingga pengembangan dan pemanfaatan luas lahan pekarangan dapat dikembangkan atau ditingkatkan secara maksimal. Penelitian ini bertujuan untuk mengetahui Tingkat keterampilan Wanita Tani dalam pemanfaatan lahan pekarangan secara intensif dan untuk mengetahui tingkat keberhasilan program pemberdayaan wanita tani dalam pemanfaatan lahan pekarangan di Desa Pekalobean, Kecamatan Anggeraja, Kabupaten Enrekang. Populasi dalam penelitian ini adalah semua wanita tani yang tergabung dalam kelompok wanita tani (198 orang). Penelitian ini dilakukan selama dua bulan Agustus sampai dengan September 2020 yang berlokasi di desa Pekalobean, Kecamatan Anggeraja, Kabupaten Enrekang.Penentuan sampel dilakukan dengan metode simple random sampling dimana jumlah sampel yang diambil sebesar $10 \%$ dari
\end{abstract}


populasi.Metode pengambilan data yang digunakan ialah observasi, wawancara, kuesioner. Analisis data yang digunakan adalah analisis deskriptif kuantitatif dengan menggunakan metode skala likert. Hasil penelitian ini menunjukkan bahwa dampak pemanfaatan lahan pekarangan rumah oleh wanita tani tergolong sangat tinggi dengan total skor 1.149 dengan tingkat keberhasilan 99,99\% hal ini berdampak positif bagi ibu wanita tani dan dapat dikembangkan secara berkelanjutan di desa Pekalobean, Kecamatan Anggeraja, Kabupaten Enrekang.

\section{Kata Kunci: Lahan pekarangan, Wanita Tani, Skala Likert}

\section{A. PENDAHULUAN}

Perkarangan merupakan salah satu potensi sumber daya lahan yang umumnya belum termanfaatkan secara baik dan terencana, sehingga potensi lahan pekarangan untuk tanaman pangan, hortikultura, tanaman obat-obatan dan lainnya masih sangat terbuka untuk dikembangkan

(Badan Litbang

Pertanian,2011).

Desa Pekalobean adalah salah satu desa yang berada di Kecamatan Anggeraja, Kabupaten Enrekang dengan luas wilayahnya $9,92 \mathrm{Km}^{2}$. Dari luas wilayah Desa Pekalobean secara keseluruhan hanya sebagian kecil lahan yang telah dimanfaatkan secara intensif, sehingga pengembangan dan pemanfaatan luas lahan perkarangan dapat dikembangkan atau ditingkatkan secara maksimal.

Ibu rumah tangga (wanita tani) memiliki peran yang cukup besar dalam mendukung kemandirian pangan gizi keluarga, yang sebenarnya. Lahan pekarangan rumah di Desa Pekalobean masih sangat kurang dimanfaatkan sebagaimana mestinya, hal ini dapat disebabkan karena beberapa faktor seperti kurangnya pengetahuan yang dimiliki wanita tani, faktor sikap wanita tani juga mencakup seperti kurangnya pengolahan lahan pekarangan yang bisa dimanfaatkan dan yang paling mempengaruhi adalah kurangnya keterampilan wanita tani dalam mengelolah lahan pekarangan rumah.

Berdasarkan hal tersebut, maka menarik untuk dikaji sejauh mana tingkat keterampilan wanita tani melalui pemanfaatan lahan pekarangan Rumah oleh wanita tani Binaan Balai Penyuluhan Pertanian (BPP) di Desa Pekalobean, Kecamatan Anggeraja, Kabupaten Enrekang.

Berdasarkan latar belakang, maka dirumusan masalah yang digunakan sebagai dasar penelitian ini adalah:

1. Bagaimana tingkat keterampilan wanita tani dalam pemanfaatan lahan pekarangan secara intensif di Desa 
Pekalobean, Kecamatan Anggeraja, Enrekang dalam beberapa Kelompok kabupaten Enrekang?

Wanita Tani (KWT) terpilih yang berada

2. Bagaimana tingkat keberhasilan di tiga dusun yaitu dusun Sipate, Dusun program pemberdayaan wanita tani melalui pemanfaatan lahan pekarangan di Desa Pekalobean, Kecamatan Anggeraja, kabupaten Enrekang ?

\section{B. METODE PENELITIAN}

\section{Tempat dan Waktu}

Penelitian ini dilaksanakan selama dua bulan mulai dari bulan Agustus September 2020 di Desa Pekalobean, Kecamatan Anggeraja, Kabupaten Enrekang yang merupakan lokasi binaan Balai Penyuluhan Pertanian (BPP) dengan program kerja pemanfaatan lahan pekarangan.

\section{Populasi dan Sampel}

Menurut suharsimi arikunto (2006) "populasi adalah keseluruhan dari subjek penelitian. Populasi merupakan sumber data yang sangat penting, karena tanpa kehadiran populasi penelitian tidak akan berarti serta tidak mungkin terlaksana”.

Populasi dalam penelitian ini adalah wanita tani yang tergabung dalam kelompok wanita tani yang aktif dalam binaan Balai Penyuluh Pertanian (BPP) Kecamatan Anggeraja yang berjumlah 198 wanita tani. Pengambilan sampel wanita tani di desa pekalobean, kecamatan Anggeraja Kabupaten Malimongan, dan Dusun Kota, yang penarikan sampel sebanyak $10 \%$ atau 20 orang wanita tani dari populasi disesuaikan dengan pendapat suharsimi Arikunto (2006)

\section{Analisis Data}

Menurut Ridwan (2008) bahwa skala liker digunakan untuk mengukur sikap, pendapat dan persepsi seseorang atau sekelompok tentang kejadian atau gejala sosial. Dengan menggunakan skala likert, dengan rumus:

$$
\mathrm{P} \frac{=\text { Rentang }}{\text { Banyak Kelas }}
$$

Dimana :

$\mathrm{P} \quad=$ Panjang kelas interval

Rentang $=$ Data terbesar - data terkecil

Banyak kelas $=5$

Dari hasil penjumlahan yang dilakukan maka dapat diperoleh ratarata/skor untuk penetapan kriteria penilaian adalah sebagai berikut:

1. Nilai maksimum

Nilai maksimum didasarkan atas skor jawaban tertinggi dikalikan dengan jumlah responden lalu dikalikan dengan jumlah kuesioner. Nilai maksimum $=5 \mathrm{x}$ jumlah responden $\mathrm{x}$ jumlah kuesioner

2. Nilai minimum 
Nilai minimum didasarkan atas skor jawaban terendah dikalikan dengan jumlah responden lalu dikalikan dengan jumlah kuesioner.

Nilai minimum $=1 \mathrm{x}$ jumlah responden $\mathrm{x}$ jumlah kuesioner Sehingga melalui perhitungan tersebut, dapat diketahui tingkat jawaban responden pada setiap item pertanyaan dengan menggunakan garis kontinum. Garis kontinum adalah garis yang digunakan untuk menganalisa, mengukur, dan menunjukkan seberapa besar tingkat kekuatan variable yang sedang diteliti, sesuai instrument yang digunakan

\section{HASIL DAN PEMBAHASAN}

Pemanfaatan lahan pekarangan di Desa Pekalobean, Kecamatan Anggeraja, Kabupaten Enrekang telah di lakukan oleh wanita sebelum adanya kegiatan program kerja Kantor Balai Penyuluhan Pertanian (BPP), namun pemanfaatanya masih terbatas pada fungsinya sebagai bermain anak da fungsi social seperti tempat pertemuan antara pemilik rumah dan tetangganya. Untuk tanaman yang di peliharanya pun terbatas pada tanaman yang mempunyai nilai estetika dan bukan tanaman yang dapat memenuhi kebutuhan pangan.

Kegiatan program kerja Balai Penyuluhan Pertanian (BPP) merupakan kegiatan memanfaatkan lahan pekarangan menjadi lebih efektif, efisien sehingga dapat memenuhi kebutuhan pangan. Potensi wanita tani dalam pembangunan pertanian dan ketahanan pangan sangat strategis. Pekarangan rumah adalah salah satu potensi yang bisa diperankan oleh perempuan. Menurut Husnah et al (2012), pemberdayaan pekarangan merupakan salah satu upaya kaum perempuan untuk meningkatkan perannya dalam pembangunan pertanian.

$$
\text { Kegiatan program kerja }
$$

pemanfaatan lahan pekarangan ini sudah lama berlangsung dan memberikan dampak positif bagi wanita tani atau ibu rumah tangga, baik dari segi ekonomi maupun dari segi social misalnya mempererat hubungan antara kelompok maupun individu wanita tani dengan warga di dusun lain

\section{Keterampilan}

Perencanaan

\section{Kelompok Wanita Tani}

Perencanaan kegiatan kelompok wanita tani merupakan menyusun rencana kegiatan-kegiatan apa yang akan dijalankan dalam rangka mencapai kinerja ang maksimal, dimana pembahasan menyangkut proses kerja lahan, pembibitan, pembuatan media tanam dan pembuatan kompos organic. Untuk dapat 
mengetahui perencanaan kelompok wanita tani, dapat dilihat pada tabel 1

Tabel 1. Keterampilan Perencanaan Kegiatan Kelompok Wanita tani di Desa Pekalobean, Kecamatan Anggeraja, Kabupaten Enrekang

\begin{tabular}{|c|c|c|c|c|c|c|c|c|}
\hline \multirow[b]{2}{*}{ No } & \multirow[b]{2}{*}{ Item Pertanyaan } & \multicolumn{5}{|c|}{ Kategori } & \multirow[b]{2}{*}{$\begin{array}{c}\text { Skor } \\
\text { Capaian }\end{array}$} & \multirow[b]{2}{*}{ Ket } \\
\hline & & $\begin{array}{c}1 \\
(\mathrm{RS})\end{array}$ & $\begin{array}{c}2 \\
(\mathrm{R}) \\
\end{array}$ & $\begin{array}{l}3 \\
(\mathrm{R}) \\
\end{array}$ & $\begin{array}{c}4 \\
(\mathrm{~T})\end{array}$ & $\begin{array}{c}5 \\
(\mathrm{ST}) \\
\end{array}$ & & \\
\hline 1 & $\begin{array}{l}\text { Merencanakan kegiatan } \\
\text { kelompok wanita tani }\end{array}$ & & & & & 20 & 100 & \multirow{3}{*}{$\begin{array}{l}\text { ST: Sangat Tinggi } \\
\text { T: Tinggi } \\
\text { S: Sedang } \\
\text { R: Rendah } \\
\text { RS: Rendah sekali }\end{array}$} \\
\hline 2 & 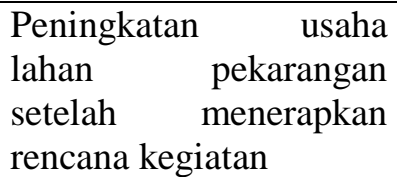 & & & & 6 & 14 & 94 & \\
\hline & Jumlah To & al Skor & & & & & 194 & \\
\hline
\end{tabular}

Sumber: Diolah Dari Hasil Penelitian, 2020

Berdasarkan tabel 1. Dapat seperti media tanaman yang akan dijelaskan bahwa peranan kelompok digunakan, penggunaan bibit unggul, wanita tani dalam merencanakan kegiatan pemeliharaan serta pascapanen. Hasil kelompok tergolong sangat tinggi dengan perencanaan kegiatan peningkatan usaha total skor 194. Hal ini membuktikan lahan pekarangan kelompok wanita tani di kesadaran dari wanita tani dapat fokuskan untuk kesejahteraan anggotanya dikatakan sangat baik karena walaupun wanita tani harus aktif berperan sebagai KWT, tetapi mereka tetap menjalankan perannya sebagai ibu rumah tangga dengan baik.

Berdasarkan hasil observasi dan wawancara dengan wanita tani responden pada umumnya mengatakan bahwa bentuk perencanaan yang paling dirasakan oleh responden saat bergabung dalam kelompok wanita tani adalah saat merencanakan kegiatan-kegiatan yang akan dilakukan. Dimana kelompok wanita tani sebagian besar sudah membuat perencanaan yang meliputi secara teknis budidaya pemanfaatan lahan pekarangan sehingga dapat menekan pengeluaran dalam pemenuhan kebutuhan sehari-hari. Seperti yang diungkapkan Depertemen Pertanian RI 1997 (dalam Samsi:2011:15) kelompok tani sebagai kumpulan para petani yang tumbuh berdasarkan keakraban dan keserasian serta kesamaan kepentingan dalam memanfaatkan sumberdaya pertanian untuk bekerjasama meningkatkan produktivitas usaha tani dan kesejahteraan anggotanya. Salah satu peran perempuan dalam pembangunan adalah dengan ikut berperan dalam menciptakan program-program yang mengarah kepada pemberdayaan perempuan dengan meluncurkan program 
pemanfaatan lahan pekarangan rumah sebagai salah satu gerakkan ketahanan pangan keluarga dan masyarakat melalui pemanfaatan lahan pekarangan. Melihat peran tersebut para perempuan memiliki kemandirian yang kuat. Sesuai pernyataan Nasri (2007:2), dalam makalahnya "Peran perempuan dalam Meningkatkan Pembangunan Pertanian".

\section{Keterampilan}

\section{Pelaksanaan}

\section{Kelompok Wanita Tani}

Pelaksanaan kegiatan kelompok wanita tani dalam menjalankan perannya terjalin baik antara sesama anggota kelompok maupun antara kelompok lain yang meliputi kesepakatan dan ketaatan anggota dalam pelaksanaan penanaman tanaman secara serentak maupun melakukan kegiatan pascapanen secara bersamaan hal ini juga didukung dengan aktifnya anggota keluarga. Pelaksanaan kegiatan kelompok wanita tani dalam menjalankan pemanfaatan lahan pekarangan rumah dapat dilihat pada tabel 2

Tabel 2. Keterampilan Pelaksanaan Kegiatan Kelompok Wanita Tani di Desa Pekalobean, Kecamatan Anggeraja, Kabupaten Enrekang

\begin{tabular}{|c|c|c|c|c|c|c|c|c|}
\hline \multirow[b]{2}{*}{ No } & \multirow[b]{2}{*}{ Item Pertanyaan } & \multicolumn{5}{|c|}{ Kategori } & \multirow[b]{2}{*}{$\begin{array}{c}\text { Skor } \\
\text { Capaian }\end{array}$} & \multirow[b]{2}{*}{ Ket } \\
\hline & & $\begin{array}{c}1 \\
(\mathrm{RS})\end{array}$ & $\begin{array}{c}2 \\
(\mathrm{R})\end{array}$ & $\begin{array}{l}3 \\
(\mathrm{R})\end{array}$ & $\begin{array}{c}4 \\
(\mathrm{~T})\end{array}$ & $\begin{array}{c}5 \\
(\mathrm{ST})\end{array}$ & & \\
\hline 1 & $\begin{array}{l}\text { Proses kerja pengolahan } \\
\text { lahan dibantu keluarga }\end{array}$ & 1 & 1 & & 3 & 15 & 90 & $\begin{array}{l}\text { ST: Sangat Tinggi } \\
\text { T: Tinggi }\end{array}$ \\
\hline 2 & $\begin{array}{l}\text { Mendapatkan bantuan } \\
\text { bibit }\end{array}$ & 1 & & 7 & 5 & 7 & 77 & $\begin{array}{l}\text { S: Sedang } \\
\text { R: Rendah }\end{array}$ \\
\hline 3 & $\begin{array}{l}\text { Pembuatan media tanam } \\
\text { untuk tanaman }\end{array}$ & 1 & & & 5 & 14 & 91 & $\begin{array}{l}\text { RS: } \\
\text { Rendah sekali }\end{array}$ \\
\hline 4 & $\begin{array}{ll}\text { Pembuatan } \\
\text { organic }\end{array}$ & 2 & 2 & 3 & 5 & 8 & 75 & \\
\hline 5 & $\begin{array}{l}\text { penanaman tanaman } \\
\text { mendapatkan arahana dari } \\
\text { ketua atau penyuluh }\end{array}$ & 1 & & & 7 & 12 & 89 & \\
\hline 6 & $\begin{array}{l}\text { Pemeliharaan tanaman } \\
\text { dibantu anggota keluarga }\end{array}$ & 1 & & 1 & 4 & 14 & 90 & \\
\hline 7 & $\begin{array}{lr}\text { Melakukan } & \text { kerjasama } \\
\text { secara } & \text { berkelompok } \\
\text { kegiatan pascapanen }\end{array}$ & 1 & & 4 & 10 & 5 & 78 & \\
\hline & Jumlah Tot & 1 Skor & & & & & 589 & \\
\hline
\end{tabular}

Sumber: Diolah Dari Hasil Penelitian, 2020

Berdasarkan data yang diperoleh hasil penelitian, menyatakan bahwa dalam tabel 2 menunjukkan bahwa pelaksanaan program paling tinggi pelaksanaan program pemanfaatan lahan ditunjuk pada item tiga yaitu pembuatan pekarangan tergolong tinggi. Berdasarkan media tanam memberikan kemudahan 
dalam pemanfaatan lahan pekarangan dengan skor 91, disusul nilai skor 90 untuk item satu dan enam yang setuju bahwa keluarga turut membantu wanita tani dalam pemanfaatan lahan pekarangan hal ini sesuai dengan pendapat Malik dan Saenoring (1999) dalam Yusuf (2011) mengungkapkan melibatkan seluruh anggota keluarga sehingga biasanya factor produksi tenaga kerja seringkali tidak diperhitungkan

\section{Keterampilan Pemanfaatan Lahan oleh Kelompok Wanita Tani}

Usaha pemanfaatan lahan pekarangan di Desa Pekalobean, Kecamatan Anggeraja, Kabupaten Enrekang, didukung oleh potensi luas area pekarangan yang dimanfaatkan untuk budidaya tanam sayur-sayuran, buahbuahan dan budidaya ternak unggas sebagai usaha konsumtif guna peningkatan gizi keluarga dan penghematan iuran rumah tangga. Berdasarkan luas lahan pekarangan wanita tani responden yang berada antara $0.02-0.10 \mathrm{Ha}$, dalam pemanfaatan lahan pekarangan pada table 3

Tabel 3. Keterampilan Pemanfaatan Lahan oleh Kelompok Wanita Tani di Desa Pekalobean, Kecamatan Anggeraja, Kabupaten Enrekang

\begin{tabular}{|c|c|c|c|c|c|c|c|c|}
\hline \multirow[b]{2}{*}{$\begin{array}{l}\mathrm{N} \\
\mathrm{o}\end{array}$} & \multirow[b]{2}{*}{ Item Pertanyaan } & \multicolumn{5}{|c|}{ Kategori } & \multirow[b]{2}{*}{$\begin{array}{c}\text { Skor } \\
\text { Capaian }\end{array}$} & \multirow[b]{2}{*}{ Ket } \\
\hline & & $\begin{array}{c}1 \\
\text { (RS) }\end{array}$ & $\begin{array}{c}2 \\
(\mathrm{R})\end{array}$ & $\begin{array}{c}3 \\
(\mathrm{R})\end{array}$ & $\begin{array}{c}4 \\
(\mathrm{~T})\end{array}$ & $\begin{array}{c}5 \\
\text { (ST) }\end{array}$ & & \\
\hline 1 & $\begin{array}{l}\text { Lahan pekarangan } \\
\text { sebagai konservasi } \\
\text { Toga (Tanaman Obat } \\
\text { Keluarga) }\end{array}$ & 1 & & & 4 & 16 & 92 & \multirow{3}{*}{$\begin{array}{l}\text { ST: Sangat Tinggi } \\
\text { T: Tinggi } \\
\text { S: Sedang } \\
\text { R: Rendah } \\
\text { RS: Rendah sekali }\end{array}$} \\
\hline \multirow[t]{2}{*}{2} & $\begin{array}{l}\text { Pemanfaatan lahan } \\
\text { pekarangan } \\
\text { menambah keindahan } \\
\text { dan keasrian rumah }\end{array}$ & 1 & & & & 19 & 94 & \\
\hline & Jumlah & Total s & kor & & & & 186 & \\
\hline
\end{tabular}

Sumber: Diolah Dari Hasil Penelitian, 2020

Berdasrkan tabel 3 maka dapat dilihat bahwa keterampilan pemanfaatan kegiatan kelompok wanita tani tergolong sangat tinggi dengan total skor 186 . Hal ini membuktikan bahwa keterampilan pemanfaatan kegiatan kelompok wanita tani di katakan sangat baik. Menurut Hidayat (2013) Menyatakan bahwa

manfaat dari pemanfaatan lahan pekarangan sebagai upaya pemenuhan kebutuhan keluarga untuk meningkatkan penghasilan, karena jika dikelolah dengan baik pekarangan rumah dapat memberikan manfaat bagi kehidupan keluarga seperti bahan pangan atau bahan obat-obatan, menciptakan lingkungan 
yang nyaman, sehat dan indah, sangat mendukung pembangunan yang berkelanjutan dan berwawasan lingkungan, karena pemanfaatan pekarangan merupakan pelestarian ekosistem yang sangat baik, dan sebagai tempat menyalurkan segala kreatifitas dan kesenangan ataupun hobi semua anggota keluarga.

Berdasarkan hasil wawancara dengan responden wanita tani pada kegiatan kelompok wanita tani sebagian besar menanam tanaman obat-obat seperti kunyit, jahe, serei dan lengkuas,atau tanaman obat-obat yang paling mudah didapat saat dibutuhkan. Tanaman obat yang dipilih untuk ditanam di pekarangan biasanya adalah tanaman obat yang biasanya dapat dimanfaatkan untuk pertolongan pertama atau obat-obat ringan, seperti demam dan batuk. Hal ini sejalan dengan pendapat Muhlisah (2006) yang mengatakan TOGA dapat dijadikan sebagai alternative obat tradisional yang paling mudah dicari saat anggota keluarga ada yang sakit. Tidak menghabiskan uang untuk membeli, dan tidak memiliki efek samping yang jauh lebih rendah tingkat bahayanya daripada obat-obatan kimia.

\section{Keterampilan Hasil Kegiatan Kelompok Wanita Tani}

Keberhasilan program pemanfaatan lahan pekarangan merupakan salah satu upaya untuk mewujudkan peningkatan kebutuhan keluarga wanita tani. Indicator hasil dari kegiatan kelompok wanita tani dalam penelitian ini diukur dengan dua indicator meliputi hasil pemanfaatan lahan pekarangan mampu memenuhi kebutuhan pangan keluarga dan menghemat pengeluaran dan kesejahteraan konsumsi rumah tangga. Hasil kegiatan kelompok wanita tani dapat dilihat pada tabel 4

Tabel 4. Keterampilan Has il Kegiatan Kelompok Wanita Tani di Desa Pekalobean, Kecamatan Anggeraja, Kabupaten Enrekang

\begin{tabular}{|c|c|c|c|c|c|c|c|c|}
\hline \multirow[b]{2}{*}{ No } & \multirow[b]{2}{*}{ Item Pertanyaan } & \multicolumn{5}{|c|}{ Kategori } & \multirow[b]{2}{*}{$\begin{array}{c}\text { Skor } \\
\text { Capaian }\end{array}$} & \multirow[b]{2}{*}{ Ket } \\
\hline & & $\begin{array}{c}1 \\
(\mathrm{RS})\end{array}$ & $\begin{array}{c}2 \\
(\mathrm{R})\end{array}$ & $\begin{array}{l}3 \\
(\mathrm{R})\end{array}$ & $\begin{array}{c}4 \\
(\mathrm{~T})\end{array}$ & $\begin{array}{c}5 \\
(\mathrm{ST})\end{array}$ & & \\
\hline 1 & $\begin{array}{lr}\text { Hasil } & \text { pemanfaatan } \\
\text { lahan } & \text { pekarangan } \\
\text { mampu } & \text { memenuhi } \\
\text { kebutuhan } & \text { pangan } \\
\text { keluarga } & \\
\end{array}$ & 1 & & & 4 & 15 & 91 & \multirow[t]{3}{*}{$\begin{array}{l}\text { ST: Sangat Tinggi } \\
\text { T: Tinggi } \\
\text { S: Sedang } \\
\text { R: Rendah } \\
\text { RS: Rendah } \\
\text { sekali }\end{array}$} \\
\hline 2 & $\begin{array}{l}\text { Mampu menghemat } \\
\text { pengeluaran dan } \\
\text { kesejahteraan konsumsi } \\
\text { rumah tangga }\end{array}$ & 1 & & & 6 & 13 & 89 & \\
\hline \multicolumn{7}{|c|}{ Jumlah Total Skor } & 180 & \\
\hline
\end{tabular}


Sumber: Diolah Dari Hasil Penelitian,2020

Berdasarkan data yang diperoleh pada tabel 4 menunjukkan bahwa hasil dari kegiatan kelompok wanita tani tergolong sangat tinggi dengan jumlah total skor 180. Diketahui bahwa indicator pemanfaatan lahan pekarangan mampu memenuhi kebutuhan pangan keluarga. Jenis tanaman yang paling banyak dibudidayakan oleh wanita tani di Desa Pekalobean adalah tanaman sayur, seperti: kangkung, kemangi, bayam, sawi dan lain-lain. Dengan adanya pemanfaatan lahan pekarangan di Desa Pekalobean, Kecamatan Anggeraja, ibu rumah tangga dapat memenuhi kebutuhan keluarga, bahkan dapat mendatangkan keuntungan secara financial yang mana sebelumnya dia membeli sayuran dipasar, dengan adanya pemanfaatan lahan pekarangan maka semua itu terpenuhi sehingga pengeluaran perekonomian keluarga dapat berkurang.

Menurut Hidayat (2013) menyatakan bahwa menfaat dari pemanfaatan lahan pekarangan sebagai upaya pemenuhan kebutuhan keluarga untuk meningkatkan penghasilan, karena jika dikelola dengan baik pekarangan rumah dapat memberikan manfaat bagi kehidupan keluarga seperti bahan pangan atau bahan obat-obatan, menciptakan lingkungan yang nyaman, sehat dan indah. Pemanfaatan lahan pekarangaan merupakan pelestarian ekosistem yang sangat baik, dan sebagai tempat menyalurkan segala kreatifitas dan kesenangan ataupun hobi semua anggota keluarga.

Faktor pendukung dari pemanfaatan lahan pekarangan yaitu dengan adanya partisipasi dari wanita tani dalam pemanfaatan lahan pekarangan rumah, untuk menanam guna untuk memenuhi kebutuhan sehari-hari, puluhan bahkan ratusan ibu rumah tangga mulai tertarik untuk memanfaatkan lahan pekarangannya.

5. Dampak Pemanfaatan Lahan Pekarangan oleh Kelompok Wanita Tani di Desa Pekalobean, Kecamatan Anggeraja, Kabupaten Enrekang

Setelah menganalisis berbagai tingkat keterampilan kelompok wanita tani di Desa Pekalobean, maka rekapitulasi indicator keterampilan pemanfaatan lahan pekarangan oleh wanita tani di Desa pekalobean, kecamatan Anggeraja,

Berdasarkan hasil dilapangan kelompok wanita tani di Desa Pekalobean, Kecamatan Anggeraja 
melakukan pertemuan rutin dengan penyuluh kantor balai penyuluhan pertanian minimal satu kali dalam sebulan. Pihak-pihak yang turut hadir dalam pertemuan rutin setiap bulan yaitu ketua kelompok, sekretaris dan anggota lainnya. Agenda rutin ini biasanya dengan pembahasan seputar tentang tanaman yang dibudidayakan, dan perkembangan kegiatan setiap kelompok. Karna setiap kelompok memiliki kegiatan yang berbeda-beda misalnya pada kelompok KWT Mahkota memiliki kegiatan rutin seminggu sekali yaitu pembuatan kripik pisang dan bawang goreng yang dijual di warung ketua kelompok yaitu $\mathrm{Hj}$, Sulianti dengan harga murah, tetapi sejak beberapa bulan terakhir KWT Mahkota tidak lagi berproduksi atau melakukan kegiatan kelompok sejak pandemic atau virus corona (Covid-19) menyebar karna adanya peraturan pemerintah yang melarang kegiatan yang mengundang banyak orang atau kumpul-kumpul.

Selain pembahasan kegiatan rutin kelompok biasanya, penyuluh akan mengusulkan kegiatan lainnya seperti pembuatan kompos organic, dari air seni kelinci, sapi dan kotoran kambing yang digunakan untuk pemberantas hama dan penyakit serta menyuburkan tanaman yang dibudidayakan.
Dari hasil pembahasan pemanfaatan lahan pekarangan rumah jika dikelola secara intensif sesuai dengan potensi pekarangan, disamping dapat memnuhi kebutuhan konsumsi rumah tangga juga dapat memberikan sumbangan pendapatan dan menghemat pengeluaran konsumsi rumah tangga. Dari hasil penelitian di Yogyakarta, Penny dan Genting (1982) dalam Anonim (1992) mengemukakan secara umum pekarangan dapat menghemat pengeluaran konsumsi keluarga antara $7-45 \%$. Hasil penelitian Lando-Lane atas nama FAO tahun 2004 dalam Satyabudi at al. (2011) juga menunjukkan bahwa hasil pekarangan merupakan sumbangan terbesar pada saat off season, serta menyumbang $25 \%$ penghematan untuk petani miskin.

\section{KESIMPULAN}

Berdasarkan hasil penelitian yang dilakukan di Desa Pekalobean, Kecamatan Anggeraja, Kabupaten Enrekang maka dapat ditarik beberapa kesimpulan sebagai berikut:

1. Tingkat Keterampilan wanita tani dalam pemanfaatan lahan pekarangan rumah secara intensif di Desa Pekalobean, Kecamatan Anggeraja, Kabupaten Enrekang mendapatkankan skor yaitu pada perencanaan kelompok wanita tani tergolong tinggi, hal ini 
sesuai dengan kemampuan wanita tani menyusun perencanaan dengan baik sehingga pemanfaatan lahan pekarangan dapat berjalan dengan baik pula, Keterampilan pelaksanaan kelompok wanita tani tergolong sangat tinggi, hal ini berjalan dengan baik karena keluarga wanita tani turut dalam pengolahan lahan pekarangan dan pemanfaatan limbah sampah rumah tangga untuk lahan pekarangan sempit; Keterampilan Pemanfaatan Lahan Pekrangan tergolong sangat tinggi. Hal ini berjalan dengan baik karena wanita tani mampu memanfaatkan lahan pekarangan sebagai konservasi TOGA (tanaman Obat Keluarga) dan menambah estetika lahan pekarangan rumah; Keterampil hasil kegiatan kelompok wanita tani tergolong sangat tinggi, hal ini sesuai dengan pernyataan responden mengatakan bahwa pemanfaatan lahan pekarangan mampu memenuhi kebutuhan pangan keluarga dan menghemat pengeluaran dan meningkatkan kesejahteraan konsumsi rumah tangga.

2. Tingkat keberhasilan program pemanfaatan lahan pekarangan rumah oleh wanita tani di Desa Pekalobean, Kecamatan Anggeraja, Kabupaten
Enrekang tergolong sangat tinggi hal ini dapat dilihat pada Perencanaan wanita tani tingkat keberhasilannya yaitu 99.99\%; tingkat pelaksanaan $98,99 \%$, tingkat pemanfaatan $99,99 \%$ Tingkat Hasil 99,99\%. Dilihat dari keberhasilan pemanfaatan lahan pekarangan rumah dapat dikembangkan secara berkelanjutan, karena program ini memberi dampak yang positif bagi wanita tani dan keluarga dimana tingka.

\section{DAFTAR PUSTAKA}

Ambrita 2015. Peran Anggota Kelompok Tani Wanita (Kwt) Laras Asri Pada Peningkatan Kesejahteraan Keluarga.Universitas Negeri Semarang.

Balai Penyuluhan Pertanian (BPP) Kec.Anggeraja, Kab. Enrekang, 2019

Badan Pusat Statistik Kabupaten Enrekang,2019

Hidayat.2013, Partisipasi ibu rumah tangga dalam pemanfaatan lahan pekarangan, Jakarta.

Husnah et al 2012.Peran Penyuluh Dalam Program Model Kawasan Pangan Lestari di Kabupaten Siak

Muhlisah, 2006. Peran Perempuan Indonesia dalam Pembangunan Pertanian. Jurnal Ilmu-ilmu Pertanian. STPP-Magelang, Yogyakarta

Nasri,2007. Peran perempuan dalam Meningkatkan Pembangunan Pertanian

Penny dan Genting, 1982. Peranan Wanita Tani dalam Perekonomi Keluarga Petani di Pedesaan (Utopia, Konseptual, dan Realita). Primordia 
Ridwan 2008. Metode Penelitian Survai. LP3ES.Jakarta.

Samsi, 2011. Strategi Penyuluhan Pertanian dalam mendukung Program

Satyabudi at al. 2011.Peran Perempuan dan Pekarangan di Sulawesi Selatan. Prosiding Seminar Nasional Optimalisasi Pekarangan untuk Peningkatan Perekonomian Masyarakat dan Pengembangan Agribisnis. Semarang

Suharsimi Arikunto.2006. Metodologi Pertanian. Yogyakarta. Bina Aksara.

Yusuf, 2011. Peran Wanita Dalam Menunjang Perekonomian Rumah Tangga Keluarga Petani Tradisional Untuk Penganggulangan Kemiskinan Di Desa Kuwil Kecamatan Kalawat. Jurnal Holistik, Tahun IX No. 17 / Januari - Juni 2011 